\title{
Improving Education Quality Through Learning Paradigm in School
}

\author{
Zulkifli M \\ Islamic State Institute (IAIN) \\ Kendari, Indonesia \\ zulkiflim58@ymail.com
}

\begin{abstract}
The aim of this study is to describe the quality of education through the learning paradigm at school. The technique of writing is through the theories of education and learning in schools, and analyzed in descriptive qualitative, by considering the triangulation technique, source, and time. The results of this study are the quality of education can be improved through learning paradigm that needs to be known and practiced by educators in the learning process in schools. Paradigm learning means here referred to as reconstruction experiences, the development of cognitive, cultural social construction, ecological, individuals collaborative, representations of individual learning style, the development of self-efficacy, empowerment and development of a biological brain.

Keyword: Education Quality, Learning Paradigm.
\end{abstract}

\section{INTRODUCTION}

The raising of diverse paradigm and learning model is always started from desire to meet students' need. If teaching and learning specification increased, so students need will also increase based on diverse learning. The nature of learning is more complex and rely on diverse of students learning needs. Learning methods could be stretching from paradigmatic until paradigmatic identic procedures.

Learning has unique paradigmatic characteristik. When learning paradigm is different based on general preferensi in the society about teaching practice, so different paradigm will be used in learning. Presented learning paradigms represent a theoretical trend of the specific initiator. Some of theorist, such as Dewey, Piaget, Vigotsky, Kolb, Wenger, Dunn and Dunn, Bandura, and others are presented to emphasize different paradigms in learning. Each paradigm also reflects the thinking of the specifications of each developer.

\section{RESEARCH METODOLOGY}

The method used in this study is the documentation which is seeking data on things orvariables such as notes, transcripts, and literature or books that explain about educations and learning paradigm.

\section{RESULTS AND DISCUSSION}

The teacher should not be empty-handed when comes to the classrooms. He/she should approach students with a set of assumptions about himself, assumptions about his/herself, studentabilities and interests, as well as about how that learning should be directed. These assumptions, wheter conscious or unconscious, would help him in mapping out strategies that will be used in approaching, designing, and managing students learning process.

The teacher should bring more than one o learning theory, in order that he could get clear prespective about the diversity aspect in learning process. Some of theoritical paradigm sometimes tried to explain the teaching and learning phenomenon as accurately as possible, but in practice the teacher will face an entirely different reality. The following will be explaining some theoritical paradigm that is generally underlying the learning practice.

\section{Learning As Reconstruction Experience}

Summarizes the Dewey's thought about Learning by saying, "Learning can be defined as a reconstruction or reorganisation of experiences that can give more meaning value and increase the ability to lead the next experience model" [1]. He then continues this synthesis with some points here. "Learning is a natural process. During his life, every individual is almost always involved in learning, trying to link some events of his life with the meanings [2].

1. Learning stimulated by the problematic situation.

2. Learning is an active process.

3. Learning occurs when individuals reflect about the actions outcomes.

4. Other Learners might just make a reflection about the same experience and draw conclusions that he turns out to be not too skilled that he needs to ask other people to do the task.

5. Learning involves the ability of learners to establish relationships among the various ideas, meanings, and events. In simple terms it can be said, "The learning generated through reflection about experience" [1].

6. Learning is a regular mental activity.

Teachers who use learning eksperiental theory will construct lessons that can give the opportunity to students to learn through experimentation, through action, or through the efforts of creating things (learning by experiment, by doing, by construction); In short, students are guided to study actively in the learning process. This learning theory is the anti-thesis against the learning theory that assumes students are simply the 
receiver of information "coming from someone who already have certain knowledge package" [3]

\section{Learning as Cognitive Development}

Focuses on how language development affects the thought process [4]. The theory emphasizes on the cognitive and developmental maturity based on the stages of age. The basic principle of theory is that children construct their own understanding. Knowledge is not a copy of reality. For that learning is a process in which a child, through assimilation and accommodation, develop their knowledge in order to value action.

According to Piaget, a child will seek a balance between knowledge structures which already owns with the new knowledge acquired through assimilation and accommodation. The first (assimilation) occurs when there is a new impression turns out to suit the cognitive scheme that have been owned by a child. Meanwhile, the second (accommodation) occurs when a child has cognitive schema change so that learning becomes increasingly raise to a higher level. Thus, new learning only happens when someone could develop his thought pattern by adapting old something.

\section{Learning As Socioculture Construction}

The theoretical paradigm is based on learning as knowledge construction among individuals and communities. As part of the social life, most of our learning process occurs in a social setting, in groups or arise as a result of interactions with other people. Paid attention to the process of developing a level-level higher-order thinking, such as memory, attention, making decisions, and the formation of concepts [5].

Although Vygotsky agrees with Piaget that language is an important means for problem solving and thought process, he asserted that the competency of a child sould be understood through three aspects:

1. "The actual Zone", which refers to what a child can do independently;

2. "Potential Zones", which refers to what a child can do to regulate itself through the help of others; and

3. "Development near zone ", which appeared in between the zone of actual and potential zones [5], which refers to "the distance between the actual developmental level, which is determined by the ability to solve problems independently and potential development level, which is determined by the ability to solve problems under the guidance of adults or by collaborating with colleagues who are more capable" [5].

\section{Learning As Ecoligist Development Process}

Consists of variety aspect influencing to human development process as well as their learning process [6]. He emphasized the social setting that happens Bronfenbrenner's theory of learning which also gives us the possibility to analyze complex and dynamic development process. Bronfen brenner defines ecological processes method as something progressive, a reciprocal adaptation between the development of the individual and aound environment.

Learning occurs when a person is affected by social development relationships that arise in between the different settings in which he participated in it.

Transition is an important component in ecological theory andit happens"when ever someone in this position where ecological environment is considered as a result of changes to the role, setting, or both" [6].

\section{Learning as Individuals Collaboration}

States that the interaction to atoher people can help individuals through the process of more positive learning than when he is just working on it's own [7]. Thus, thoughts, ideas, and understanding will always develop in the individual, but not apart from other around people influence.

That is, by interaction an individual may develop his broader knowledge. In this perspective, Wenger presents learning conditions to explain human interelasi in which its learning is often happens in it. The conditions of learning have always been an important part of social relations.

Explain that the individual is the central point, and as a person in the world [8];[9]. He was a member of a particular community of sosiokultural were also marking the learning process in it. "Communities of are groups of people in the context of practical and specific social who sharing the attention of something they used to do or learn to become better when they interact regularly".

6. Learning as Repsresentation of Individual Learning Style.

That educational reformation generally is as the important key towards efforts to improve the responsibility of the teachers in understanding the students need [10]. "Describing learning styles as patterns of consistent behavior and performance, owned by each individual to approach their learning experience" [11]. "Learning styles, thus, is a blend of cognitive, affective, and behavioral psychological characteristic becomes an indicator of how a student learns, interacts with, and respond to their learning environment" [12]

In Dunn and Dunn theory,"the first of each element above indicates the analytic processor. This happens when the left brain is more dominant because students are constructing information with systematic and structured way to complete a project at a time. Meanwhile, the second of each element above from (a) to (e) represents the right-brain dominance or called as global processors, where students need to see the overall picture and works with many projects simultaneously without having to get it done in a specified time " [3]; [13].

\section{Learning as Self-Efficacy Development}

Any individual trying to control the events that affect their lives [14]. The ability to produce result and avoid something unwanted could give support for 
personal control development. Strong effectiveness feeling is reall needed for psychological health of human beings. This is because the level of motivation, affective conditions, and one's actions are almost always based on what he believed.

\section{Learning as Empowerment}

Theories of different empowerment generally have same one theme, the main goal is to strengthen the ability of individuals to control their personal events that occurred in situationsof school everyday. Empowerment perspectives focuses on how human needs and interestsis, how one expresses interest and desires, and how operations result of a person related to the indicators of success [15], [16].

\section{Learning as Development of Biological Brain.}

The biological theorists focuson anatomical changes a nd psychological appeared in brain when learning takes place. They are trying to describe how a memory is formed and also wanted to understand the variables that affect the process of formation. The theorist-brainbased linking health issues, such as exercise, emotions, pressures, nutrition, and positive attitude to the use of a healthy brain. Furthermore, an effective learning can be implemented [17];[18];[19]. Naturally, the education odbiological brain-based is found based on the simple observation that brain was formed by the experiences of the individual shaping and modifying those owned experiences can forming and modifying his brain.

\section{CONCLUSION}

Learning paradigms outlined above, is a reflection on the underlying theoretical perspectives. Learning could be meant as a reconstruction of an individual experience. He also could be meant as an early commencement of cognitive development of individuals. Learning can be considered also as a result of the reconstruction of sosiokultural in which individuals live and lear. On the other hand, the study can also be emansipatif, because he must show his efforts in empowerin students. He could even very biological markers could be due to the functioning of the right brain and left brain learning while it lasts. In some ways, the study also reflects the diversity of the individual learning style. This means that learning can only happen if the teachers really appreciate the difference in learning style students and trying to design the learning that can meet the diverse student needs.

\section{REFERENCES}

[1] Bogner, D. 2008. Conversations and Unpublished Narrative on A Synthesis of Dewey's Learning Theory and Personal Reflections on Teaching and Learning. New York: Molloy College, Rockville Centre.

[2] Bogner,D.1990.John Dewey's Theory of Adult Education and Adult Development. University of Kansas.

[3] Schiering, M., Buli-Holmberg, J., \& Bogner, D. 2008. A Model for Developing Academic and Social Cognition, Character Development and the Interactive Book Report. Norwegia: the University of Oslo and Teacher's College, the University of Bergen.

[4] Piaget, J. 1936/1963. The Origins of Intellegence in Children. New York: W.W. Norton and Company.

[5] Vygotsky, L. S. 1978. Mind in Society. Cambridge, MA: Harvard University Press.

[6] Bronfenbrenner,U.1979. The Ecology of Human Development. New Haven, CT: Harvard University Press.

[7] Wenger, E. 1998. Communities of Practice: Learning, Meaning, and Identity. Cambridge, MA: Cambridge University Press.

[8] Wenger, E. 2006. "Communities of Practice: A. Brief Introduction”.'http://ewenger.com/theory/index.htm. Diakses 30 April 2016.

[9] Howley, P., Reynolds, R., and Southgate, E. 2016. The Teaching Discipline Doesn't Matter? An Assessment of Preservice Teachers' Perception of the Value of Professional Experience in Attaining Teacher Competencies. Australian Journal on Teacher Education (AJTE), Vol. 41/Issue 10, pp 30-41

[10] Keefe, J. W. (ed.). 1979 “Learning Styles: An Overview”. Student Learning Styles: Diagnosing and Prescribing Programs (1-17). Reston, VA: National Association of Secondary School Principals.

[11] Keefe, J. W., \& Languis, M. 1983. "Description of the Learning Style Profile”. J. W. Keefe \& J. S. Monk (ed.). NASSP Bulletin (43-53). Reston, VA: National Association of Secondary School Principals.

[12] Schiering, M. 1999. The Effects of Learning-Style Instructional Resources on Fifth Grade Suburban Students' Metacognition, Achievement, Attitudes, and Ability to Teach Themselves. St. John's University.

[13] Bah, H. and Adamu, Y. 2016. The Role of Educational Institutions in Instituting Ethics in Student Life: Islamic Science Initiative. International Journal of Sciences: Basic and Applied Research (IJSBAR) pp 24-31

[14] Bandura, A. 1997. Self-Efficacy: The Exercise of Control. New York: Freeman.

[15] Dunst, C., Trivette, C., \& Deal, A. 1994. "Enabling and Empowering Families". C. Dunst, C. Trivette, \& A. Deal (ed.). Supporting and Strengthening Families (2-11). Cambridge, MA: Brookline.

[16] Bisht, A. and Godiyal, S. 2016. StudyAddiction Among Higher Secondary Girls Students. International Journal of Advanced Multidisciplinary Research (IJAMR). Vol.3, Issue 9. Pp 1-5

[17] Jensen, E. 2008. Brain-Based Learning: The New Paradigm in Teaching. Thousand Oaks, CA: Corwin Press.

[18] Damasio, A. 1994. Decartes' Error: Emotion, Reason, and the Human Brain. New York: Putnam Berkeley Group.

[19] Brandt, R. 1999. Education Need to Know about the Human Brain. Phi Delta Kappan, 81 (3), hlm. 235-238 